\title{
Settler farming, agricultural colonisation and development in Katanga (Belgian Congo), 1910-1920
}

\author{
Charlotte Vekemans and Yves Segers
}

KEYWORDS: settler farming, colonial policy, Katanga, Belgian Congo.

JEL CODES: F22, N5, N97, Q18.

om 1908 to 1920 , the Belgian Ministry of Colonies organised the first state-
led agricultural colonization efforts in Katanga, Belgian Congo. This article ex-
amines the complex interactions between public and private actors and how they shaped a colonial agricultural policy. Mission Leplae had a very difficult start and was terminated after ardent discussions in the Belgian Parliament, despite the support of the Agricultural Service. This migration initiative exposed the different views and even tensions between the opinions of technical experts such as agronomists and the ideas of the colonial hommes politiques and private actors, both in Belgium and in the Congo. In this article, the image of a homogeneous colonial state acquires nuance as we unravel and analyse the daily realities and initiatives of these first Belgian agricultural settlers in the broader framework of Belgian colonial politics. When the alliance between the State, the mining sector and agricultural settlers ceased to exist, because European agriculture was not developing fast enough and geopolitical interests had changed, the government stopped supporting the colonization project. After the First WorldWar, the number of Belgian farmers in Katanga began to increase again, mainly thanks to support from the private sector. This article shows how state support was an important but not decisive factor in the survival strategies of a settler community. 


\section{Agricultura colonial, colonización y desarrollo en Katanga (Congo Belga), 1910-1920}

\section{PALABRAS CLAVE: agricultura colonial, política colonial, Katanga, Congo Belga.}

\section{CÓDIGOS JEL: F22, N5, N97, Q18.}

e 1908 a 1920, el Ministerio de Colonias belga organizó los primeros esfuerzos
de colonización agrícola liderados por el Estado en Katanga (Congo Belga).
Este artículo examina las complejas interacciones entre actores públicos y privados y cómo moldearon una política agrícola colonial. La Misión Leplae tuvo un comienzo muy dificil y fue terminada después de fuertes discusiones en el Parlamento belga, a pesar del apoyo del Servicio Agrícola. Esta iniciativa de migración expuso los diferentes puntos de vista entre las opiniones de expertos técnicos, las ideas de los hommes politiques y los actores privados. En este artículo, la imagen de un Estado colonial homogéneo adquiere matices a medida que analizamos las realidades e iniciativas diarias de estos primeros colonos agrícolas belgas en el marco más amplio de la política colonial belga. Cuando la alianza entre el Estado, el sector minero y los colonos agrícolas dejó de existir, porque la agricultura europea no se estaba desarrollando lo suficientemente rápido y los intereses geopoliticos habian cambiado, el gobierno dejó de apoyar el proyecto de colonización. Después de la Primera Guerra Mundial, el número de agricultores belgas en Katanga comenzó a aumentar de nuevo, principalmente gracias al apoyo del sector privado. Este artículo muestra cómo el apoyo estatal fue un factor importante pero no decisivo en las estrategias de supervivencia de una comunidad de colonos.

Received: 2018-05-04 - Revised: 2019-11-06 - Accepted: 2019-11-13

Charlotte Vekemans [orcid.org/0000-0002-1232-5430] is PhD Researcher and Teaching Assistant at Ghent University (Belgium). Address: Department of Conflict and Development, Universiteitsstraat 8, 9000 Gent (Belgium).E-mail: charlotte.vekemans@ugent.be

Yves Segers [orcid.org/0000-0003-4897-945X] is Professor of Rural History and Director of the Interfaculty Centre for Agrarian History (KU Leuven, Belgium). Address: Interfaculty Centre for Agrarian History, Atrechtcollege, Naamsestraat 63, B-3000 (Belgium).E-mail:yves.segers@kuleuven.be 


\section{INTRODUCTION}

The difficulty seems to arise from the Belgian's love of his comforts. He needs his cup of coffee in the morning and his glass of beer during the day. In Katanga, we occasionally have to do without those things.

This was Minister of Colonies Jules Renkin's statement in the House of Representatives on January 25, 1911, when he tried to explain the difficult start of the agricultural colonisation in Katanga. Despite the initially broad support from the government, Stateled agricultural colonisation would come to a halt as early as 1913. Contrary to expectations, Belgian farmers showed little enthusiasm to settle in Katanga. This project was the first colonial endeavour of the Belgian government in the Congo, following the takeover after international criticism on the inhuman practices under King Leopold II. It brought together geopolitical, economic and cultural concerns of the Belgian government. As such, it is an ideal case study to look at this early period of Belgian colonial rule. But most importantly, it is also the first colonial agricultural project, and as such gives us insight into the earliest beginnings of Belgian colonial agriculture and policy views. The quote by Renkin seems to indicate that Belgians were just not "tough" enough to venture into colonial settlement projects, a view that is clearly too narrow to understand exactly what issues and conflicts led to the failure of this white settlement project. This article analyses the opinions and complex interactions between public and private actors during the first agricultural settlement project in the Belgian Congo (1908-1920), and the way they influenced colonial policy and eventually led to the abandonment of the settlement project by the Belgian government.

As such, this article is an important addition to extensive literature on colonial agricultural settlements. Over the past decade, the attention of researchers to migration movements and settler farming in colonial Africa has increased significantly. The discussions covered mainly British colonies such as Northern and Southern Rhodesia, South Africa, Nyasaland and Tanganyika (Morapedi, 2014; Bonello, 2010). In this extensive historiography, a great deal of interest focused on the manner in which colonial policy wanted to steer these European farming communities. A first group of studies focuses on identity formation in settler communities. They show that the racial categories and the different communities were topics of colonial social engineering. After all, the formation of different and heavily segregated communities was vital for the colonial administration. It was necessary both to maintain white domination, and to have a loyal European population to rely on. Julie Bonello, Katja Uusihakala, Samuel Coghe, and Claude Lützelschwab, among others, demonstrated how much the western farming communities in Africa were socially influenced and shaped to fit into the ideological and political projects of the 
metropolitan and the local colonial administrations (Stoler, 1989; Lützelschwab, 2007; Uusihakala, 2015; Coghe, 2016; Bonello, 2010).

A second group of researchers analyses the economic situation, the political and economic policies of the colonial authorities towards white settler farmers. In a recent comparative study based on three pairs of comparisons each focused on a crop (Ghana and Ivory Coast for cocoa, Tanzania and Kenya for coffee, and Malawi and Zimbabwe for tobacco), Ewout Frankema, Erik Green and Ellen Hillbom conclude that the long-term success of settler agriculture required sustained political support and their research shows that when native agriculture proved to be more efficient and cheaper, political support for European settler farming could disappear quickly (Frankema, Green \& Hillbom, 2016). Many other studies also conclude that agricultural colonisation could have only been successful with help from a wide range of government measures that were advantageous to the white, European farmers and plantation owners. At the same time, the interests of local African farmers were ignored and even counteracted (Mosley, 1982; Morapedi, 2014).

White farmers initially had to deal with numerous problems. The most important were undoubtedly labour scarcity and the primitive transport network. Certainly, in settler economies with a nascent mining sector, such as Katanga, the labour shortage caused tensions. Both agriculture and industry needed a large workforce, and this resulted in shared and conflicting interests between the actors involved (white farmers, indigenous farmers, industry, colonial authorities). In colonial British Africa, it was mainly the white agricultural settler communities in Southern Rhodesia and South Africa that managed to get long-term government support. They could count on effective governments and well-developed road and railway networks. In South Africa, this initially resulted in an alliance between the gold mines and a large group of progressive maize farmers (sometimes referred to in the literature as a marriage between maize and gold), but when settler farmers failed to provide sufficient food production for industrial workers, the alliance and state aid came under pressure.

Researchers, such as Wazha Morapedi and Isaac Mazonde, emphasized the importance of the political influence white farmers managed to build in Botswana, and they introduced the concept of settler empowerment (Mazonde, 1989). If European farmers failed to succeed in obtaining sufficient influence and were unable to command the necessary financial and material support, the chances of success for expensive agricultural colonisation were small. The colonial government was then more inclined to opt for an agricultural system that relied heavily on local African farmers (Frankema, Green \& Hillbom, 2016). In French West Africa and Portuguese West and East Africa, settler farmers also struggled with the dynamism and agency of the local farmers. 
The focus on the political negotiations in this article also fits within a broader trend in which the homogeneous, all-controlling image of the colonial State is questioned. Especially within the historiography of Belgian Congo, the State has until recently been portrayed as a monolithic block, capable of directing and suppressing the entire population (Young, 1994; Jewsiecicki, 1977, 1980). However, recent studies in colonial history, following critiques and new insights from researchers such as David Scott and John Comaroff, show the many faces and conflicting ideas of the colonial State in Africa, and in this way also give us a more nuanced view of the agency of the various non-state actors in the colony (Musemwa, 2017; Beusekom, 2002; Mwatwara \& Swart, 2016). In the study of the Belgian Congo, these critiques have hardly been examined before and this study supports this more nuanced view.

Agricultural colonisation in Katanga has not received much attention until now. The studies by Bruce Fetter, Bogumil Jewsiewicki, and Vita Foutry on -farmers- migration to the Belgian Congo offer only a superficial sketch (Jewsiewicki, 1979; Fetter, 1968; Foutry, 1983). The doctorate of Katanti Mwitwa discusses farmer migration in Katanga in more detail but does not address the complex relationships between public and private actors on the one hand, and the tensions between policy makers and civil servants in the metropolis and colony on the other. His thesis also puts more focus on the later periods in the colonial agricultural policy, especially the inter- and post-war period (Mwitwa, 1988).

Despite the short duration of the Mission Leplae and the small number of settler farmers involved, this is an interesting case for several reasons. The colonization project sheds an innovative light on the early political and socio-economic history of the Belgian Congo. This article focusses on the discussions and conflicts between the various levels of government in this earliest period of Belgian colonial rule. It examines how the various colonial policy makers weighed their thinking on the outcome of this first colonisation experiment in Katanga, and to what extent non-state actors could influence agricultural policy in the colony. The focus on agricultural colonisation exposed the tensions between the policy of technical experts such as agronomists and veterinarians, the ideas of the colonial men of politics, and private players such as the Comité Spécial du Katanga (CSK), the Ligue Coloniale du Katanga and the Compagnie Foncière, Agricole et Pastorale du Congo (known in short as the Pastorale). We use the discussions and difficulties that came with this agricultural colonisation to nuance the image of a homogeneous colonial State. In a recent article by Matthew Stanard, the usefulness of a single analytic frame, which explicitly chooses not to disconnect the developments in the colony from the metropolis (a concept proposed by Cooper and Stoler), was put into question regarding the Belgian Congo (Stanard, 2014). This article shows that in situations such as 
this state-led migration movement, we require the single analytic frame to understand fully the complex colonisation and the, sometimes, difficult relationship between the metropolis (Brussels) and the colony (Katanga). Furthermore, this article exposes the problem that the colonial government had in ensuring that the food supply for the mining workers prevailed. If the white settlers were unable to achieve this, support for the colonization project stopped and more support for indigenous farmers followed. Because after the First World War the Comité Spécial du Katanga took over the helm of agrarian colonisation, our research -based on public and private archives, contemporary publications and parliamentary reports- is limited to the period 1908-1920.

\section{KATANGA: A SOUGHT-AFTER REGION}

Covering an area of $496,871 \mathrm{~km}^{2}$, Katanga is almost seventeen times larger than Belgium, and it was already highly sought-after by the end of the nineteenth century (see Map 1). The soil was rich in tin, copper, uranium, and radium and contained extensive diamond deposits. Several industrialists and investors organized prospecting trips and charted the economic opportunities. From neighbouring Northern and Southern Rhodesia, which were run by the British South Africa Company, Cecil Rhodes encouraged the establishment of British companies in Katanga. This caused immediate tension with the Belgians, leading to their establishment of the CSK in 1900, an initiative of the Belgian king and the Congo Free State on the one hand, and the Compagnie du Katanga, a private company that was mainly active in the mining sector, on the other. This new parastatal organization, which had important political and economic powers, had the task of consolidating Belgian sovereignty over the region, though it was powerless to prevent foreign influence from continuing to increase in the coming years. The burgeoning mining industry attracted a lot of European and especially British settlers and investors. The free trade agreements concluded at the Berlin Conference in 1885, allowed foreigners the right to settle freely in Katanga. In 1906, the Compagnie du Katanga even merged with the British Tanganyika Concessions to form the Union Minière du Haut-Katanga (UMHK). At that time, barely 30\% of Europeans in the Congo Free State and the Katanga border region had Belgian nationality (Buelens, 2007; Katzenellenbogen, 1973).

When the Belgian State took control of the colony in 1908, the Belgian position in Katanga became once again the subject of heated discussions. According to then current colonial ideology, an area was only really in possession of the metropolis if it was also effectively occupied and "colonised". The growing foreign presence in the region caused the Belgian authorities many headaches, especially when both Imperial Britain and France started expressing their doubts as to whether the small country of Belgium was 
able to control the immense Congolese territory. Other concerns included the peripheral location and the poor transport connection from Katanga to other Congolese regions (Vantemsche, 2007). All transport to and from Katanga from 1910 was via railways which were in the hands of British investors and ran across Rhodesian and South African territory. Quick and direct railway connections with the Congolese port of Matadi, located on the Atlantic Ocean, and with the African Great Lakes region in the east, only came into being after the First World War. In 1925, Katanga was connected via Bukama to PortFranqui in the province of Kasaï, from where Leopoldstad (now Kinshasa) was easy to reach by boat (Robert, 1950).

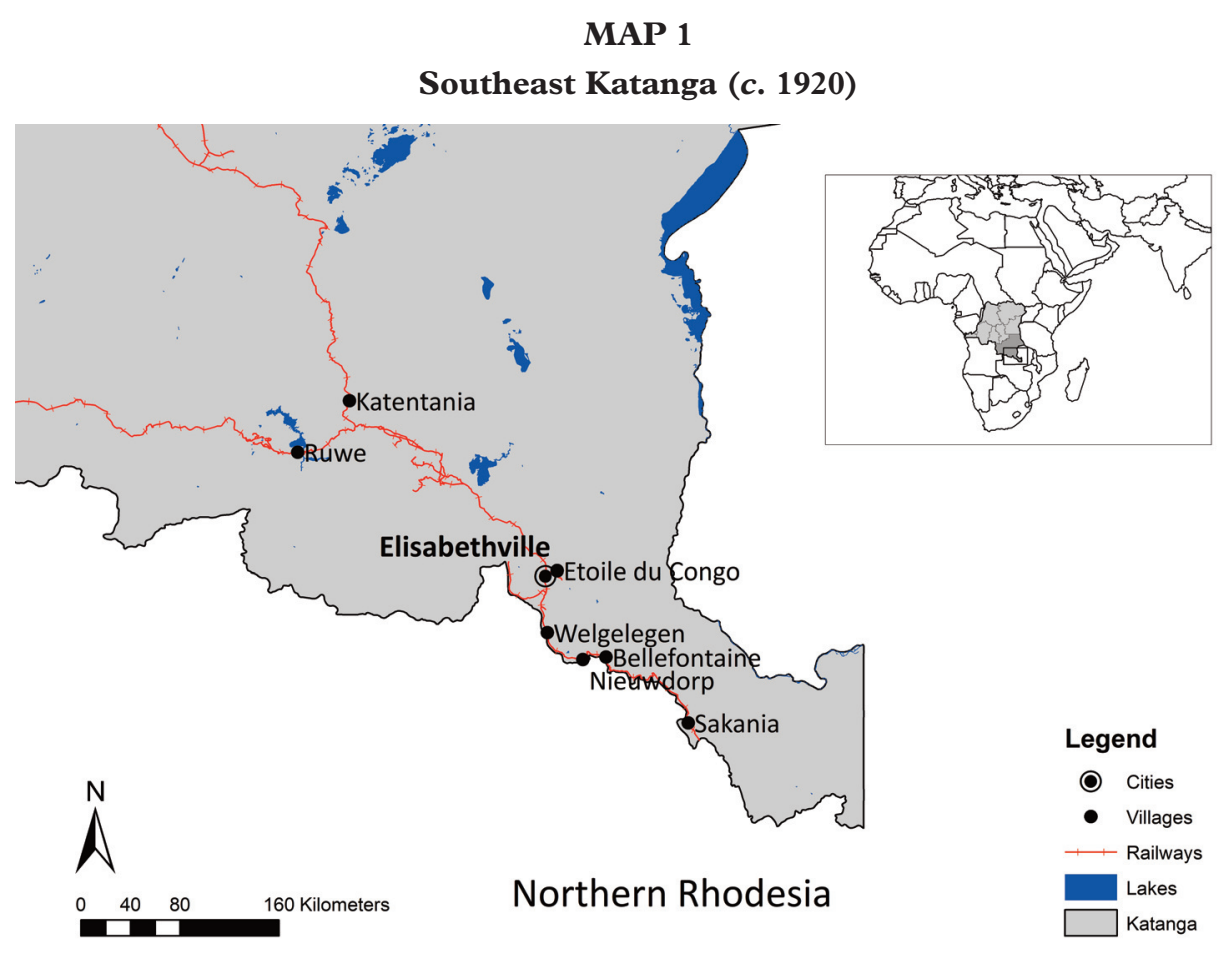

Source: map made by dr. Dries Claeys.

The Belgian government was well aware that the 1910 opening of a new rail link with the nearby British colonies would attract a lot of Britons and Boers from South Africa. This could prove to be problematic, since the British government still had not recognized the boundaries of the Belgian Congo. Reports and correspondence show that the Minister of Colonies, the Catholic Jules Renkin, closely monitored those migration movements. The perception of an ever-growing presence of so-called foreigners created an increasing 
sense of urgency to "secure" Katanga within the Ministry, as well as in the Chamber of Representatives ${ }^{1}$. The rapid development of the mining sector also generated an increasing demand for food, both for the growing group of indigenous workers and for the westerners who were active in and around Elisabethville. Since its inception in 1900, the CSK had established several experimental agricultural stations, each with a small vegetable garden and a herd of livestock. And there were initiatives from the mining industry itself, promoting the cultivation of European crops (e.g. potatoes, vegetables, and fruit). However, production was insufficient to meet the demand, which meant that Katanga was largely dependent on importing food from the surrounding British colonies ${ }^{2}$.

A number of initiatives attempted to address the difficulties mentioned above. The CSK argued for measures that would not only stimulate agricultural development and food production, but would also convince more Belgians to settle in Katanga. By specifically attracting Belgian farmers, they wanted to cultivate the land and literally allow it to be taken over by Belgians. Agricultural enterprises were seen as a pénétration pacifique. In contrast to the comings-and-goings of all kinds of fortune seekers, government officials, and workers, who usually only stayed in the colony for a few years, the migrant farmers gave it a permanent colonial population. This would prevent the British from denying the Belgian character of Katanga any longer. In August 1908, the Belgian head of the region Haut-Luapula sent a letter to the CSK in which he warned of the influx of foreigners and pressed for the settlement of Belgian farmers in order to keep Katanga's mineral riches in Belgian hands. The letter was forwarded from the director of the CSK Léon Tonneau to the Belgian Minister of Colonies. Correspondence such as these show the collaboration of private and public actors that turned out to be crucial for the settlement project $^{3}$.

For these reasons, the Belgian government created an Immigration Fund to reimburse the passage of suitable Belgians to the colony as early as 1910. Only Belgians who had an honourable trade and clean criminal record were allowed to travel to the colony at the government's expense. By requiring the candidates to have a minimum capital of $500 \mathrm{BEF}$ (about half a year's wage of a farm worker in Belgium; 12,4 Euro) or to submit an em-

1. Archives Ministry of Colonies (AA), AEII 3610, Colonat-Immigration, Correspondence J.H. Luus and S.P.J. van Vuuren, December 30, 1912; Rapport sur l'immigration Boer au Congo par Ernst de Brunswick consulat belge à Entebbe, au ministre des Affraires etrangères, December 19, 1913; Correspondence Ernst Lademacher to Governor-general in Boma, May 25, 1911; Parlementaire handelingen, February 2, 1910, pp. 421-427, and February 10, 1910, pp. 511-512.

2. Comité spécial du Katanga (1950: 52-53).

3. AA, AEII 3610, Colonat-Immigration, Rapport du Comité Spécial du Katanga au ministre des Colonies, August 4, 1909. 
ployment contract of at least three months with a white employer, the Belgian government aimed to exclude poor whites from the colony. According to colonial officials and intellectuals, whites were not allowed to perform -heavy- physical work; they had to manage and supervise the work done by the local Congolese population. This was also legitimized by so-called hygienic regulations and advice, which stated that whites were not capable of performing heavy labour in the high local temperatures. The indigenous population was sufficiently adapted to the tropical climate and could therefore be used as porters and as a labour force in the mining industry or on the land (Bevel, 1935; Foutry, 1988; Segers, 2003). All these measures were aimed at keeping up the prestige of the white population in the colony, a policy very similar to policies in other colonies. The fear of losing the strict hierarchical divide between white and black population, as Ann Stoler has traced in the archives of the colonial rule of the Dutch Indies, was shared by Belgian administrators. But, as Stoler shows with her detailed discussion of colonial categories and diverging realities, government did not achieve full control over the immigration of so-called poor whites (Stoler, 2010). As we will see when discussing the social profiles of the Belgian settlers, many of them did not come from wealthy families and much government intervention was needed to keep the categories "straight"

\section{THE PASTORALE: PRIVATE INITIATIVE AS A PIONEER}

At more or less the same time as the first initiatives of the government in collaboration with the parastatal CSK, a number of private actors put their effort into two concrete projects to start colonisation -including farmers- in Katanga. The Compagnie Foncière, Agricole and Pastorale du Congo, or simply Pastorale, was one of the first projects. On the initiative of King Leopold II, this company was founded on November 23, 1909, just a few weeks before his death ${ }^{5}$. The Pastorale consisted of a select group of business leaders and aristocrats who, working together, raised a budget of 1 million BEF to start an agricultural colony in Katanga. The list of associates and board members reads like a who's who of Belgian aristocracy, as well as figures from the business world and high finance. Some prominent figures from the Société Générale, such as Vice-Governor Joseph Devolder and director Jean Jadot, and banker Baron Edouard Empain, appear here. High profile names from the industrial world included Ernest Solvay, Evence Coppée, and Leon Mondron. Edmond Drugman was not only adviser to Leopold II; he was also closely in-

4. AA, AGRI 694, completed questionnaires of farmers Mertens on social background and previous work experience; City Archives Ghent (SAG), Ligue Coloniale Belge du Katanga, 10, Correspondence of Belgians from the colony to the Ligue.

5. AA, Conseil colonial, procès-verbal des séances, 1911-1912, pp. 7-23. 
volved in founding the UMHK, Forminière, and the Compagnie Chemin de Fer du BasCongo au Katanga. The close involvement of these figures illustrates the extent to which agricultural colonisation arose from industrial motives and opportunities. The Pastorale hoped therefore to serve mainly the burgeoning mining sector by producing European food and increasing the Belgian presence within the region ${ }^{6}$.

In 1910, the company organized two exploration trips. The first departed in January under the guidance of agricultural engineer Adrien Hock, but little is known about that mission. The second one led by Leopold Frateur, left a month later and included South Africa ${ }^{7}$. Professor Frateur, a zoologist at the Catholic University of Leuven and executive director of the Pastorale, noted during his trip that the development of a profitable agricultural sector in Katanga would face serious difficulties, because Congolese workers were scarce and the tsetse fly was a permanent threat to livestock farming (Woestenborghs, Hermans \& Segers, 2005). The reports from Hock and Frateur were discussed in the Colonial Council (which advised the Minister of Colonies in his policy) and within the Ministry. However, they would not discourage the Pastorale or the colonial authorities. The Pastorale received a concession of no less than 150,000 hectares from the $\mathrm{CSK}^{8}$.

Only a few months after the first farm was started, the Pastorale sent thirty-five settlers -including two women- to Katanga. The farm covered forty hectares for vegetable cultivation, an orchard with 600 fruit trees, and young livestock. In addition, the Pastorale also set up two livestock farms: Luabala-kraal and Katentania, with about 700 cattle. The first group of settlers initially did an internship on these model farms and then began working as tenants on one of the farms set up during 1910-1911 (Leplae, 1913). However, the Pastorale was not able to develop as planned. The company mainly attracted fortune seekers, who also quickly returned to Belgium or settled in Elisabethville as labourers or craftsmen. The working and living conditions there were better than in the inaccessible Congolese countryside. Moreover, farmers were also faced with disease and wild animals, and there was a problematic shortage of Congolese workers. The Pastorale therefore adopted a different approach in 1911, deciding to drop the tenancy system, and take on ten new settler farmers and nineteen employed workers ${ }^{9}$. However, in the following year, it already

6. AA, ST(11) 120, Compagnie foncière, agricole et pastorale du Congo.

7. AA, Conseil colonial, procès-verbal des séances, 1911-1912, pp. 7-23; AA, AEII 3610, ColonatImmigration, Rapport Frateur pour la Pastorale, October 28, 1910; Correspondence Hock-Pastorale, August 19, 1910.

8. AA, Conseil colonial, procès-verbal des séances, 1911-1912, pp. 7-23; AA, AEII 3610, ColonatImmigration, Rapport Frateur pour la Pastorale, December 28, 1910; Correspondence Hock-Pastorale, August 19, 1910.

9. AA, Conseil colonial, procès-verbal des séances, 1911-1912, pp. 7-23. 
appeared that the Pastorale's capital was insufficient to provide such extensive support. On July 30, 1912, the company was dissolved. The farms, the remaining livestock, the newly constructed access roads and bridges, the plantations, and accompanying documentation were bought up by the Belgian State, in view of the implementation of its programme of agricultural colonisation and immigration. The sales price amounted to $685,000 \mathrm{BEF}$, including no less than 450,000 BEF for livestock (respectively 16,985 and $11,158$ Euro $)^{10}$. Since 1910 , there had been an increasingly vociferous opinion in the House of Representatives that the Belgian State could best take over the agricultural settlement project itself. Representatives were suspicious of the CSK's major influence and felt it best to limit private initiative to industrial development ${ }^{11}$. The parastatal organisation was viewed as the main cause for the deficit within the colonial budget. The Catholic representative Emile Tibbaut, who later took part in the support of other agricultural colonisation efforts, was fierce in his critique during the discussion of the budget in January $1911^{12}$. It seemed that the harmonious collaboration between private and public actors had come to a screeching halt.

\section{AGRICULTURAL MISSION: EDMOND LEPLAE AND THE AGRICULTURAL SERVICE}

Because the scope of the Immigration Fund remained too limited, and for the above-mentioned political and economic reasons, Minister Jules Renkin had already given the newly established Service de l'Agriculture (The Agricultural Service, 1910) the task of preparing a plan to develop an agricultural settlement project in Katanga. Edmond Leplae, state agronomist and professor at the Catholic University of Leuven, was appointed as the director of the Agricultural Service. The Service was composed of colonial officials and technical experts who, in line with contemporary ideology, had set themselves the goal of bringing modern civilisation and western agricultural practices to the colony in a rational and efficient manner. Leplae had previously built up expertise in colonial agriculture and was a strong proponent of modernization through white settlement and the associated planned agriculture (Leplae, 1909). The plan (the Mission Agricole, also called Mission Leplae) was the Agricultural Service's first major project. It was crucial in legitimising the Service and perfectly suited to putting Leplae's ideas into practice. For example, he argued that his employees had to be sufficiently active in the colony itself. The

10. LePlae (1913: 330-336); AA, ST(11) 120, Dissolution et nomination de liquidateurs, compagnie foncière, agricole et pastorale du Congo. Société anonyme à Bruxelles, July 25, 1912 .

11. Parlementaire handelingen, January 27, 1911, pp. 486-488.

12. Parlementaire handelingen, January 26, 1911, pp. 470-473. 
colonial agricultural policy, drawn up mainly in the metropolis, needed support with sufficient practical and local knowledge. The Agricultural Service produced agronomic maps of the various regions and tried to estimate the production and general potential of both indigenous and European -plantation- agriculture. In that way, the government also wanted to set out a more explicitly scientifically based agricultural policy (Kerckhofs $\&$ Segers, 2014) $)^{13}$. Leplae and his colleagues took inspiration from the successful agricultural practices in British and Dutch colonies such as Java, Malaysia, and Southern Rhodesia, with which they became acquainted during study trips. They discussed the results and insights during study group meetings and distributed them through publications and magazines, such as the Bulletin Agricole du Congo Belge ${ }^{14}$.

One might ask, what was the opinion of the Belgian agronomists about the agricultural opportunities in Katanga? In their opinion, agriculture was still in a completely "natural" state. Thus, they categorized Congolese agricultural practices as primitive and not very efficient. In reality, the region was familiar with short and long-distance trade in foodstuffs and had a tradition of highly diversified agriculture, which had thus far protected the indigenous population in the event of even a single crop failure. Several communities had a specific agricultural or hunter-gatherer culture and were dependent on each other to supplement their own yields (Wilkie \& Curran, 1993; Drachoussoff, Focan \& Hecq, 1991). The classic Bantu system was practised on the savannah in the north. This involved trees and shrubs being burned down and the cultivation taking place on mounds. Grass and woody materials were used as fertilizer. There was no rotational system. The main crops were sorghum, corn, éleusine and manioc, and to a lesser extent, peanuts and sweet potatoes were also grown. In the wooded areas in the south, the locals used the chitemene bemba. After the forest was cut down, the trees were burnt and the abundant ashes served as soil fertilizer. The crops were grown on the ashes. Livestock was practically non-existent in Katanga in the pre-colonial period; the locals only kept chickens and goats. In addition, picking and hunting were also important in the traditional food supply. The Belgian agronomists did not qualify the nomadic agriculture and the slash and burn techniques used by the local population as efficient, modern or civilised. They described the Congolese as lazy, conforming to their own ignorance of indigenous practices (Mwitwa, 1988; Leplae, 1913: 330-336).

13. Parlementaire Stukken, Rapport de la section centrale fait par M. Tibbaut du budget du Congo belge, December 3, 1909; Administration du Congo belge-Rapport de 1910, September 14, 1910; Royal Museum for Central Africa in Tervuren (KMMA), Papiers Fuchs, 224: correspondence RenkinFuchs, October 22, 1910.

14. Including among others the Société belge d'études et d'expansion, the Groupe d'études coloniales de l'Institut Solvay, the Institut Royal Colonial Belge and in the Bulletin de la Société Royale de Géographie d'Anvers. 
Within the broader agrarian policy for the whole colony, the specific policies for Katanga stood out. Whereas in the other provinces the focus was on stimulating cash crops such as cocoa, palm oil, and cotton, the agricultural sector in Katanga had to serve mainly the mining industry and the burgeoning capital Elisabethville. The project thus united the technical experts' scientific-modernity ideology, the economic aspirations of the industrialists in the region, and the geopolitical wishes of colonial policy makers, both in the colony and in the metropolis. That approach ensured that the project could count on a general appreciation within the Belgian Parliament. All political parties agreed that the development of the agricultural economy should be a priority and that it should be taken up by the State ${ }^{15}$.

Leplae and his staff's plans for Katanga envisaged a leading role for a network of "Belgian farms". A flourishing agricultural sector not only meant a stable source of income, but it would also serve as a spearhead in the "civilising offensive" they had in mind. As such, the plan fitted into a broader worldwide trend of social engineering through colonial policy (Bonello, 2010; Coghe, 2016). In Katanga, Belgian farmers had to set a good example to the indigenous people, show them the principles of modern -sedentary and commercial- agriculture and thus get to know the value of hard work. In addition, the Belgian authorities hoped that a modernization of indigenous agriculture would result in an adaptation of Congolese family structures to western standards ${ }^{16}$. Polygamy among the indigenous peoples was a thorn in the side of the Belgian State and certainly the Catholic Party and missionary congregations. They hoped to promote a monogamous lifestyle through the example of white Belgian farm families (husband, wife, and a group of children). In other words, agricultural policy and more specifically farmer migration served not only political and economic objectives, but it was also a way to discipline the Congolese and to adapt their lifestyle to European standards ${ }^{17}$.

This vision arises from the Catholic agricultural ideology, which had a great deal of influence in Belgium at the time and was inspired by the corporatist school in France and the Agrarromantik in Germany. While the socialist Belgian Workers Party expanded its power base in the cities among the workers, the Catholic Party sought its votes among the farmers. They were seen -and idealized-as bearers of tradition, as healthy and moral

15. Parlementaire Stukken, Rapport de la section centrale fait par M. Tibbaut du budget du Congo belge, December 2, 1910.

16. Parlementaire handelingen, January 25, 1911, pp. 454-458; Parlementaire Stukken, Rapport de la section centrale fait par M. Tibbaut du budget du Congo belge, December 2, 1910.

17. Parlementaire handelingen, February 1, 1911, pp. 519-525; Parlementaire handelingen, January 25, 1911, pp. 454-458; Parlementaire Stukken, Rapport de la section centrale fait par M. Tibbaut du budget du Congo belge, December 2, 1910. 
citizens. For the Catholic Party, the farmers provided the base of every nation. Farming families were large with many children, which boosted the national birth rate. In addition, they played a crucial role in society because they supplied the rest of the population with food. Above all, the farmers were considered as the conservative and stable forces in society. They were bound to the land and opinion was that they were less inclined to adopt revolutionary ideas. Farmers were also known as defenders of Church and faith. Edmond Leplae was a member of a corporatist-inspired study circle in Leuven. In this way, science was linked directly to prevailing ideas about the organization of both European and colonial society (Molle, 1989).

After months of preparations in the metropolis, the activities of the Agricultural Service moved to Katanga in the spring of 1911. Edmond Leplae opted to coordinate the project locally. He arrived in April 1911, after a long journey through South Africa and, whilst spending a few weeks on a prospecting trip with a dozen employees, he explored the possibilities of setting up agricultural exploitations in the short term. Strikingly, they mainly explored the region around Elisabethville and the river valleys along the border with Northern Rhodesia. During this trip, the majority of Leplae's employees encountered the African bush for the first time. In his letters to Minister Renkin, Leplae was very positive about the opportunities -the climate was ideal and there were enough suitable plots of land. Leplae's outspoken optimism was in stark contrast to the rather negative reports from Hock and Frateur, who had been commissioned by the private organisation Pastorale $^{18}$.

Leplae decided to concentrate the first phase of the colonisation in the region between Sakania and Elisabethville, both ideally located near the recently constructed railway. At that time, the road network in Katanga was barely developed at all. The railway was the only efficient form of transport for shipping agricultural supplies and food products to regional consumption centres. The Agricultural Service set up two new villages in 1911, namely Bellefontaine and Nieuwdorp, and the scientific stations Welgelegen and Kinsengwa. According to Leplae, Bellefontaine's location was not only ideal from an agricultural point of view. In a letter to Minister Renkin on October 4, 1911, he noted It is essential that this locality should be very favourably located regarding the matter of political surveillance and administration of the far south of Katanga. Agricultural Service employees had already ensured that the Congolese workers had brought part of the land into cultivation. In practice, this meant burning the bush, cutting down trees, clearing the soil of roots and stones and, if necessary, installing an irrigation system. The necessary material, seeds, planting stock and livestock were already on site. Elisabethville became the

18. AA, AGRI 627, Correspondence to Minister Renkin, May 28, 1911. 
home of the Agricultural Service's head office for the province of Katanga. By mid-1911, twenty-four employees were involved in the Mission Agricole, including not only several agronomists and agricultural engineers, but also a veterinarian and a civil engineer ${ }^{19}$.

\section{5. "COLONS AGRICOLES" UNDER THE TROPICAL SUN}

Thus, everything seemed ready for receiving the first migrant farmers. The selection of suitable candidates took place in collaboration with the Ligue Coloniale Belge du Katanga (or Ligue). This private organization, founded in Brussels in 1911, comprised a group of volunteers from the petit bourgeoisie and worked closely with the government. The Ligue was not restricted to providing information about migration and daily life in Katanga through organizing lectures and weekly information sessions, and publishing articles in local newspapers ${ }^{20}$, as it also maintained personal contacts with candidate settlers and advised the Ministry over which of them was eligible for effective migration and therefore also for guidance and financial support. The Ligue originally endorsed the importance of agricultural colonisation and invited Leplae to speak about his plans for the region. However, after the first, rather negative letters from the colonists began to arrive, the Ligue chose to mainly supply workers and craftsmen, who had better chances of finding financial opportunities within the industrial region ${ }^{21}$.

Belgian settlers of the first group were welcomed in the new "municipalities" of Nieuwdorp and Bellefontaine, to give them the opportunity to recover from the long journey and to acclimatize. From the scarce visual materials saved from the time, it appears that the initial accommodation consisted mainly of temporary tents and huts, with very basic amenities. There were Agricultural Service employees on location, a Belgian doctor, and a priest, who also ran a school for the children who were travelling with the settlers. During their stay, the migrant farmers could explore the area, familiarize themselves with local farming conditions and retrain. During the first six months, they had the benefit of free housing and they received an allowance to buy food (30 BEF or 0.74 Euro per month). They worked for the Agricultural Service until the lease farms designated for them were ready. In practice, the first settlers had to stay in the welcome villages for about a year, because it took much longer than planned to build the first farms. Moreover, the cultivation of the land was difficult, because there were insufficient Congolese workers.

19. AA, AGRI 627, Correspondence to Minister Renkin, October 4, 1911.

20. [...] car j'apprends que sur plusieurs points du pays se forment des comités en vue de nous seconder pour l'extension de l'immigration. Parlementaire handelingen, January 25, 1911, p. 462.

21. SAG, Ligue Coloniale Belge du Katanga, 6, Procès-Verbaux des Séances. 
The population in Katanga was limited and the mining sector also needed Congolese workers (Hock, 1912) ${ }^{22}$. The Agricultural Service supported the settlers in other ways. Employees regularly visited the outlying farms and provided advice, e. g. about improving calcium levels in the soil. They also distributed free or cheap planting material, seeds, as well as large and small livestock. In the course of time, they also provided ploughs, draft animals, and steam engines for deforesting land, irrigation, or road building ${ }^{23}$.

The way in which the Agricultural Service organized agricultural colonisation in Katanga was clearly inspired by the situation and approach in Southern Rhodesia (Leplae, 1915a ${ }^{24}$. Just as in Katanga, the British colony there was also land-locked, and settler farming was entirely at the service of the mining industry. From the turn of the century, a unique settler identity emerged, its primary characteristics being a focus on the nuclear family and on promotion and support of a white community. In addition, there was strong British patriotism in Rhodesia and there too settler farmers were viewed as a threat to national -colonial- unity. Though the Belgian settlements would never reach the same numbers as the Southern Rhodesian settler population, the colony served as a source of inspiration for the Belgian government. Among other matters, Leplae cited the pioneers of agricultural colonisation there as the ultimate examples of perseverance and diligence in difficult circumstances (Bonello, 2010). Agricultural colonisation had indeed experienced a difficult start in Southern Rhodesia, and this was something with which the Belgians could identify. Plagued by drought and locust plagues and without accessible markets, the first European settlers in Southern Rhodesia were only able to practice autarchic farming. Real agricultural development did not start until 1908, but immediately took off thanks to numerous support measures from the British South Africa Company. This company was also able to build on a vast colonial network and based its work on years of expertise from South Africa and the decades of colonial experience of the British Empire. Agricultural development in Southern Rhodesia only focused on European farmers, for whom a white agricultural policy was developed. Scientific research and various supporting measures such as cheap agricultural credit and low land prices formed the cornerstone of this policy (Palmer, 1977). European agriculture's difficult start followed by great success was hugely appealing to the Belgians' imagination. But Southern Rhodesia was not the only source of much needed inspiration. Under Leplaes leadership, important contacts were made with agronomists in the Dutch and British Indies and with the German, British, and French colonies in Sub-Saharan Africa (Kerckhofs \& Segers, 2014) ${ }^{25}$.

22. LePlae (1913: 449-452).

23. AA, AGRI 627, Correspondance Leplae-Service Agricole au Katanga, May 4, 1916.

24. AA, AEII 3610, Colonat-Immigration, Rapport Frateur pour la Pastorale, October 28, 1910.

25. Parlementaire Stukken, Administration du Congo belge-Rapport de 1910, September 14, 1910, 
It is not easy to reconstruct how many Belgians and foreigners, both farmers and nonfarmers, settled in Katanga before, during and shortly after the Mission Agricole. Compiling a civil register was very difficult and inaccurate. There was also a great deal of turnover; many settlers remained in the colony for only a short period and returned home disappointed; some died from tropical diseases. Table 1 brings together information from various sources and, in particular, reveals some important trends.

\section{TABLE 1}

\section{Evolution of Belgian and European population and number of Belgian and} European farmers in Katanga, 1910-1920 26

\begin{tabular}{|c|c|c|c|c|c|c|c|c|c|c|c|}
\hline & 1910 & 1911 & 1912 & 1913 & 1914 & 1915 & 1916 & 1917 & 1918 & 1919 & 1920 \\
\hline Belgian farmers & 1 & & 32 & 23 & 20 & & 27 & & 34 & & 60 \\
\hline European farmers & 13 & & & & 17 & & 12 & & 15 & & 40 \\
\hline Belgian population & & 313 & 907 & & & & 949 & 1,071 & & & 1,780 \\
\hline European population & 361 & 747 & 1,760 & & & & 1,980 & 2,469 & 2,571 & & 3,33 \\
\hline
\end{tabular}

Source: AA, Rapport annuelle du Congo belge, 1911-1920.

As we can see, the white, western population increased nearly tenfold between 1910 and 1920. The number of Belgians increased from about 300 in 1911 to 1780 in 1920. The share of Belgians in the total European population fluctuated around approximately half during that period. In 1911, they represented $40 \%$. It took until 1920 before the number of Belgians rose to represent around 55\%. The number of Belgians and Europeans increased particularly in the years 1911-1912 and even more strongly during the early years following the First World War. This mainly concerned colonial officials, servants, and labourers employed by western companies. In Nyasaland, Tanganyika, Northern Rhodesia and other African colonies, the number of settler farmers also increased profoundly from 1920 onward (Palmer, 1986; Nindi, 1987; Hillbom \& Jenkin, 2018). The settlers in Katanga were attracted by the high wages in the then burgeoning Elisabethville, as well as in the mining industry. Farmers only represented a very small minority. A report written by Leplae in 1921 indicates that the Belgian State sent seven hundred and fifty-five male settlers to Katanga between 1910 and 1920. Only thirtytwo of them were agricultural settlers ${ }^{27}$. Of all settlers who went to Katanga via the state

p. 28; Administration du Congo belge-Rapport de 1911, September 29, 1911, pp. 28-29; Administration du Congo belge-Rapport de 1912, October 24, 1912, pp. 29-30; Administration du Congo belge-Rapport de 1913, October 30, 1913, p. 52.

26. AA, Rapport annuelle du Congo belge, 1911-1920.

27. Parlementaire Stukken, Administration du Congo belge-Rapport de 1913, October 30, 1913, p. 46; SAG, Ligue Coloniale Belge du Katanga, 8, liste des dossiers envoyés à Mr. Goffart, directeur délégué au ministre des colonies. 
program, there remained only one hundred and twenty-nine in 1921 (barely a fifth of their number $)^{28}$.

The evolution of the western farming population in Katanga broadly followed the trend described above. In 1910, only one Belgian farmer would have been active in Katanga, while there were thirteen foreigners (mainly British). In the following years, their number increased. In 1914, the Agricultural Service listed twenty Belgian farmers and seventeen others of European origin. From 1916, the presence of western farmers accelerated. In 1920, there were sixty active Belgian farmers in Katanga and forty foreigners. They managed about eighty-five farms ${ }^{29}$. The initiatives of the Pastorale and the Mission Agricole -however limited and short-lived- apparently not only led to the number of Belgian farmers increasing from 1911-1912, but also to their number being greater than their foreign counterparts.

Between the end of 1911 and 1913, thirty-two farmers (accompanied by 28 women and children) left for Katanga under government supervision. From that group, nine had already returned home in 1913, accompanied by sixteen women and children ${ }^{30}$. During the same period, six farming families went to Katanga on their own initiative. It is not immediately clear why some chose to go to the colony on an independent basis. Did they not meet the Agricultural Service's requirements for those who could benefit from financial support? Or was it because they insisted on their independence, and wished to settle in a location of their preference? In any case, these migrants could still call on the advice and even practical support from the state agronomists. Another striking factor is that, despite the colonial authorities' concern about strengthening the Belgian presence in Katanga, the total number of foreigners actually increased. Moreover, in some cases, the Agricultural Service provided them with substantial material support and technical advice. In addition, from 1912-1913, Belgian farmers were permitted to migrate without financial reserves if they already had a friend or family member in Katanga ${ }^{31}$. Both observations show that, in the course of time, pragmatism prevailed over theoretical and ideological principles. It is not clear exactly how the farmer selection process was run. There is only one surviving completed standard questionnaire from a candidate migrant farmer. The document provides an insight into the points to which the colonial authorities paid

28. The single Belgian colon in 1910 was Mr. G. Hanssens, see Leplae (1913: 350).

29. Parlementaire Stukken, Administration du Congo belge-Rapport de 1920, December 14, 1921, p. 65 .

30. Parlementaire Stukken, Administration du Congo belge-Rapport de 1913, October 30, 1913, p. 46.

31. AA, AGRI 693-694, Dossier individuels. 
attention. The factors looked into included the composition of the family, the head of the family's education, and the professional activities of any sons over the age of fifteen. The available capital, the farmer's specific agricultural activities in Belgium and membership of agricultural organizations were also discussed. And of course, their motivation was a point for consideration. Joseph Mertens, from Rillaar, responded in early 1913 as follows: I want to leave Belgium to have a better opportunity to expand the farms and gain bigger profits in the Belgian Congo. A few months later, he and his brother left for Katanga (Foutry, 1988).

Little is known about the origins and social profiles of the "agricultural settlers". We only know the home locations of a mere ten farmer migrants who settled in Katanga through government support: six were from Flanders, three from the Brussels region, and only one was from Wallonia. The vast majority were not very prosperous. Leplae described them as petits agriculteurs (small farmers) (Leplae, 1915b, 1918, 1921). Overall, the records show that the strict migration policy that was supposed to ward off so-called poor whites did not really result in strict selection for these early settlers. The brothers Jules and Louis Goethals, aristocrats from the Brussels area, were an exception. They were still young when they settled in Katanga in 1911, but they succeeded in starting a thriving business that would expand through to the 1930s. The social background of Belgian settler farmers only changed after the First World War. From then on, a small but dynamic and wealthier group comprising former civil servants and ex-employees of western colonial companies decided to invest in a plantation or start their own farm $^{32}$.

At various times, Leplae expressed his disappointment about the limited enthusiasm among Belgian farmers for settling in Katanga. He pointed out the relatively good situation for farmers in Belgium at that time as the primary reason. A second cause was the lack of adventurousness and desire to migrate to distant foreign countries, especially among farmers with wealth to back them. In comparison with other-western- European countries, overseas migration was indeed not very popular in Belgium. However, since 1910 numerous articles appeared in magazines, newspapers and brochures in which the extensive possibilities for farmers and artisans in Katanga were described in fine detail. The region was thus presented to a wide audience as a true El Dorado, characterized by a growing economy and industry, a pleasant climate and many opportunities to make one's fortune. In various publications, agricultural colonisation was presented as a much needed pioneer for a colonisation de peuplement which would lead to a rich and prosperous colony. However, Table 1 shows that the propaganda had only limited recruiting power (Adam, Bolle \& Chaudoir, 1911; Goffart, 1912).

32. AA, AGRI 693, Colons au Congo belge vers 1913, Dossier Goethals (diverse). 


\section{FARMERS IN KATANGA}

The actual agricultural activities and the support measures of the Agricultural Service tell us more about the reality behind this pioneer plan. The start-up and expansion of farms was very slow in the first years, which was also the case in other African colonies. Most farms had limited size. In mid-1914, the average area was 19.1 hectares. The smallest farms held about five hectares, and the largest enterprise covered 47 hectares (Ferme Gen in Nieuwdorp). By the end of 1914, the average farm size had risen to 22.1 hectares, mainly due to the start-up of several larger enterprises and the expansion of existing farms. The eighty-hectare Ferme Nicolas in Lufira was the largest. The total cultivated area, by western migrants, rose from 648.5 to 868.5 hectares in the second half of 1914 . From four enterprises, it was possible to chart the evolution year-by-year. Graph 1 shows that the size of the farms only increased considerably from 1915-1916. The Goethals and Mertens brothers clearly opted for scaling up, while the farms belonging to the Léonard and Moyaert brothers remained much more limited in size.

In the early years of agricultural colonisation, following the recommendations of the Agricultural Service, small businesses concentrated on vegetable cultivation. But it was not a decisive success. The sales market was too limited, and the prices were low, certainly in comparison with the effort invested. Moreover, the farmers faced many practical problems such as insects and an excessively humid climate. Transport to Elisabethville was cumbersome and time-consuming. The auction, originally set up to make sales more efficient, was abolished in 1915 through necessity. The two settlers who still focused on vegetable cultivation sold their products directly from door to door in Elisabethville ${ }^{33}$. In addition to vegetables, most settlers also cultivated maize and potatoes (sweet and regular) in this initial phase, supplemented with one or two smaller crops such as pumpkins, sorghum or manioc. During the First World War, an increasing number of settlers began to invest in fruit trees. So, in 1915, the Goethals brothers produced a huge variety of fruit including limes, lemons, apples, oranges, mandarins, and figs. Livestock and poultry also became more popular from 1914-1915, especially on the wealthier farms. Thus, in 1915, Ferme Smith had no fewer than 112 cows, 60 heifers, and 60 bulls. However, this was a risky investment as the tsetse fly remained an acute threat until the 1920s. This was the first time that state veterinarians succeeded in keeping the livestock alive for longer, through thorough deforestation and disinfectant baths (Leplae, 1918, 1921) ${ }^{34}$.

33. Leplae (1915b: 72-91); LePlae (1918: 3-28); L'Agriculture Au Katanga (Congo belge) (1918: 136-163); Leplae (1921: 3-36, 134-148); AA, Rapport Annuelle du Congo belge, 1911-1920.

34. LePLAe (1915b: 72-91). 


\section{GRAPH 1}

Evolution size agricultural exploitations in Katanga (hectares), 1912-1921 35

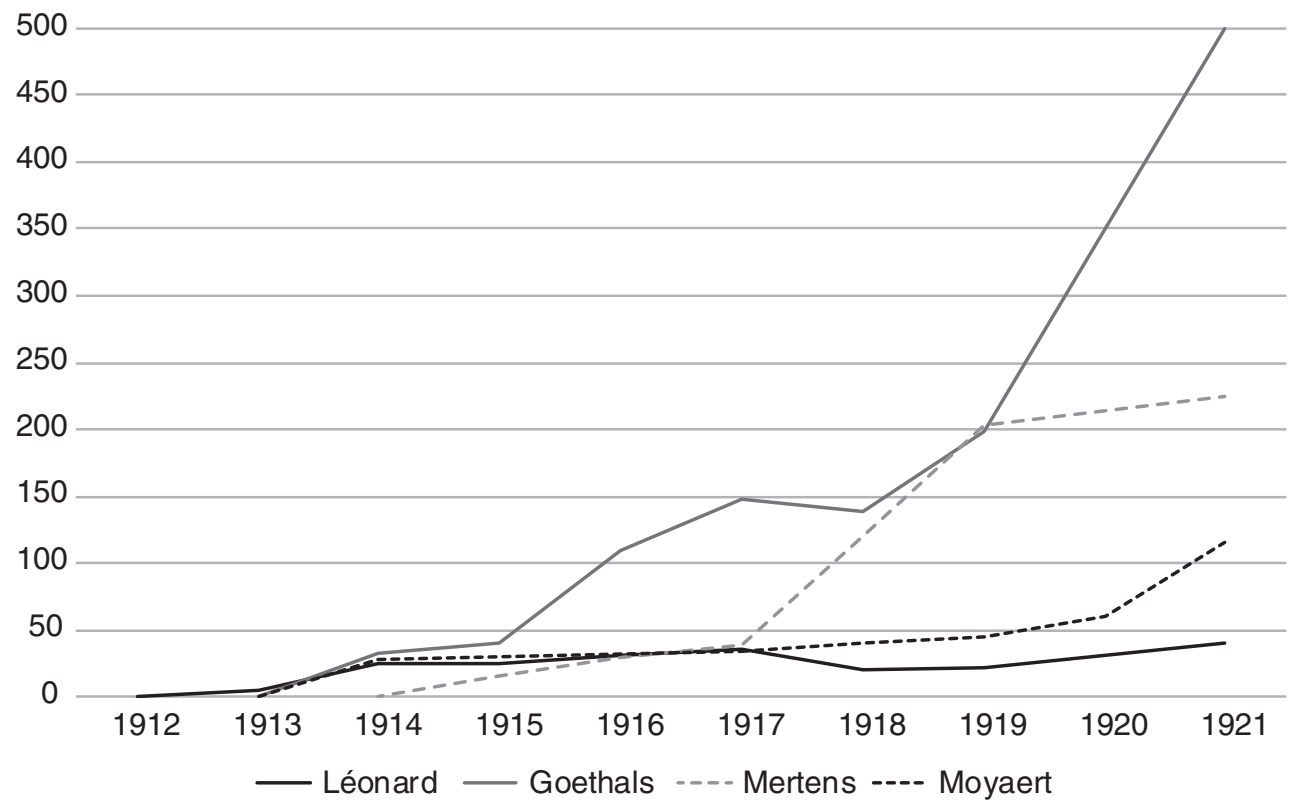

Sources: Leplae (1915b: 72-91); Leplae (1918: 3-28); L'agriculture au Katanga (Congo belge) (1918: 136163); Leplae (1921: 3-36, 134-148); AA, Rapport Annuelle du Congo belge, 1911-1920.

From 1915-1916, some farms were able to increase greatly the area of cultivated land. In the early years, it was difficult for them to fully exploit the value of their allocated concessions, in particular because there was a lack of sufficient workers, as well as draft animals to clear the land and then cultivate it. Many settlers complained about this shortage of local labour -and in their opinion, the high costs. Ferme Nicolas, which had a concession of 850 hectares in 1915 and of which only $10 \%$ was under cultivation, employed 30-40 Congolese workers. However, the Agricultural Service wished to set up as many new enterprises as possible. Expanding the existing farms did not fit into the politics of pénétration pacifique. However, during the First World War this strategy changed, and the Agricultural Service released additional funds (draft animals, ploughs and capital) to support the expansion of well-functioning farms. Despite Leplae's explicit preference for whole families running farms in Katanga, it turned out to be mainly brothers who did well there. The Goethals, Mertens, Noote, and Moyaert brothers are good examples (Leplae, 1921). They all arrived in 1911 or 1912, were still active in the primary sector a decade later, and they were widely praised for their dedication. However, that did not

35. AA, Rapport Annuelle du Congo belge, 1911-1920. 
mean that they could all count on the same support. For example, it is striking that the Goethals brothers were able to rely on a lot more subsidies and help (about 100,000 BEF or 2,478.94 Euro in financial and material support in 1913 and 1914) than the Moeyaert brothers could (with only about 31,000 BEF or 768.47 Euro between 1913 and 1919) ${ }^{36}$. These larger enterprises were the ones that eventually focused on monoculture and plantation. In their quest for innovations, they also benefited from a remarkable amount of support from the Agricultural Service agronomists. They gradually expanded their practical and scientific knowledge about Katangese agriculture. Over the course of time, the Service had an experimental farm, a laboratory for chemical and physiological soil analysis, a meteorological station, and a test centre for fruit and other tree cultivation. Much attention was also paid to pilot studies as Leplae underlined in 1918: It was necessary to find methods to use in cultivation and rearing that would make the best use of the land, and that result could be obtained only by methodical experiments, directed by a technical service made up of agronomists, cultivators, and veterinarians (Leplae, 1918, 1921) ${ }^{37}$.

\section{PROBLEMS AND PROTESTS}

As we described above, not all farmer migrants were successful. The agricultural colonisation in Katanga did not progress in the way that Leplae and Renkin had hoped. Some contemporary observers even described the Mission Agricole as a total failure. The reasons for this are twofold: the region was less suited to European agriculture as initially thought -the factor endowments- and the unanimous support in the colony and metropolis fell away quickly. Settler farmers in Katanga struggled with many problems that also manifested themselves in other colonies such as Nyasaland and Northern Rhodesia. Firstly, the Belgians' expectations regarding the region's opportunities were never fulfilled. In fact, the Pastorale initially overestimated the fertility of agricultural land in Katanga, and the Agricultural Service made the same mistake later. This was probably due mainly to the low level of familiarity with the region, although we should not forget the political motives for increasing the Belgian presence in Katanga in the short term. Nevertheless, the agronomists and settlers reported that the yields of several farms had already fallen sharply after the first year. Natural fertilizers were scarce, partly due to the problems of keeping livestock alive over the long term. That was a second obstacle. During the early years, the majority of the animals died after a few months, due to the tsetse fly. In addi-

36. AA, AGRI 693, Dossier Goethals, Assistance accordée par la colonie à MM. Goethals frères, without date; AA, AGRI 694, Dossier Moyaert Détail des indemnités en espèces accordées aux colons Moyaert, October 8, 1919.

37. LePlae (1915b: 72-91). 
tion, artificial fertilizers were scarce and expensive, because they had to be imported from South Africa (Hock, 1912). The lack of pack animals and agricultural machinery made it difficult to prepare and remodel the plots of agricultural land. The labour shortage constituted a third major problem in the sparsely populated Katanga, just as in other African colonies. This would give the colonial administration in Katanga -and by extension throughout the colony-headaches for years to come. Agriculture and the export-oriented and highly lucrative mining sector in particular, required a large group of workers. This is why, after the First World War, the colonial authorities promoted the migration of workers from the densely populated Rwanda-Urundi to Katanga (Booth, 2013).

The poor transport connections in the region presented a fourth obstacle, which meant that sales and distribution of the food produced were very difficult. Life in Katanga was extremely expensive, which made the start-up phase far more difficult for the farms ${ }^{38}$. But the farmer migrants did not rest on their laurels. In 1916, fourteen settlers, assisted by the Agricultural Service, set up a cooperative buying and selling organization. The goal was to be able to purchase a range of supplies cheaper and to organize sales more efficiently. This also offered a better way to deal with imports from the nearby British colonies -and mainly Northern Rhodesia-, even if the real competition came from closer to home.

A fifth explanation for the problematic development of agricultural colonisation was the great difficulty the Belgian farmers had adapting to the tropical climate, hygienic conditions, and daily life in Katanga. Many settlers struggled with health problems caused by diseases such as typhus and malaria ${ }^{39}$. Most settlers had no experience with African agriculture and their western agricultural knowledge was not much use to them. The soil, the crops and varieties were different; working with Congolese workers was a very new experience, and daily life in Katanga differed profoundly from that in Belgium. The farming families could not rely on a trusted social network of family and friends. Moreover, the settlers lived and worked at relatively long distances from each other and from the only city with any western style, Elisabethville, and that only increased the sense of social isolation. Perhaps that is why the Agricultural Service opted to build the new farms according to the Flemish model. Leplae stated in a report that the farms and villages were reminiscent of home: It's like being on a small farm near a Belgian village in Flanders or Brabant (Leplae, 1911) ${ }^{40}$.

38. AA, AEII 3610, Extrait du presse, fournal du Katanga, December 14, 1912; SAG, Ligue Coloniale Belge du Katanga, 9, private correspondence to the Ligue.

39. SAG, Ligue Coloniale Belge du Katanga, 9, private correspondence to the Ligue.

40. AA, AGRI 627, Note au sujet de la Mission de M. Leplae, August 17, 1916. 
But a decisive factor turned out to be the competition with indigenous farmers. The colonial administration in Elisabethville, where most of the farmers had settled around, knew that indigenous farmers could produce far more foodstuffs for far cheaper prices. Especially the local staples, needed for the indigenous workforce in the mines, was produced with more ease by the local farmers. This observation also applies to other colonies. According to Palmer, the performance and agency of indigenous farmers was one of the main reasons for the problems of settler farmers in Nyasaland, Southern and Northern Rhodesia (Palmer, 1986; Green, 2016; Hillbom \& Jenkin, 2018). It is one of the reasons why the settlers eventually focused on more complex and capital-intensive crops, such as fruit and animal production ${ }^{41}$. The administrators also quickly realized that it would not be Belgian farmers that would populate the region and bring prosperity, but the traders, engineers and craftsmen involved in the industrial centers. The overall cost of living in Katanga was very high and many in the administration had hoped the European farmers could lower these daily costs with their produce (Fetter, 1968). However, due to the difficult conditions, the farmers produced very little and their products were expensive. The local administrators criticized the expensive settlement scheme and preferred large plantations to the small settler farms. The different views on the settlement scheme created tension between the local administration, the local agricultural service and the Ministry of Colonies. Because of the direct involvement of the director of the Agricultural Service, Edmond Leplae, the local agricultural service and settlers felt themselves backed by the metropolitan administration. The Vice-Governor of Katanga, together with the rest of the local administration vehemently disagreed with the way the settlement scheme was rolled out and felt they were more competent in deciding which agricultural measures were necessary in the province.

In 1913, the Vice-Governor attempted to introduce grand scale maize cropping to supply the industrial centers instead of the diversified cultures the farmers had planted. The maize project went directly against the plans set up by Leplae and the Vice-Governor was called back by the Minister after complaints from the Agricultural Service ${ }^{42}$. The Minister of Colonies not only ended the maize scheme but also explicitly reprimanded the Vice-Governor and his administration for not complying with the course set out by the metropolitan services. Minister Renkin pointed out to the Vice-Governor in three different letters that it was the duty of the Agricultural Service to draw up a scientifically

41. AA, AGRI 627, Projet de statuts d'une société coopérative agricole, May 11, 1916; AA, AGRI 627, Correspondence between Leplae and the Minister of Colonies, May 12, 1916.

42. AA, AGRI 627, Correspondance entre E. Leplae et J. Renkin, May 12, 1916; AA, AGRI 752, Correspondance J. Renkin et vice-governour du Katanga March 28, 1913, February 24, 1913, 13-061913. 
founded agricultural policy and that only the experts could make the right decisions, even if they came mainly from Brussels ${ }^{43}$. According to Renkin, only the experts should decide which farms were assigned to particular settlers, and determine which crops had to be promoted. In essence, the discussion was about two points: to what extent the colony -and Katanga in particular- benefited from a centrally controlled policy, and what was the role of agricultural experts. The correspondence clearly shows that the Vice-Governor wanted more autonomy. He did not agree, for example, with Leplae's vision of using the available resources for starting more new farms. He wanted to expand existing and well-functioning enterprises first. But for Leplae, geopolitical interests superseded the quest for higher food production. On March 28, 1913, the Minister emphasized once again the main objective of the Mission Agricole: It is not only intended to bring in farmers, but also the largest possible number of Belgian nationals. We must make every effort to create as many enterprises as possible and to have them in the hands of Belgians. The Minister also asked that sufficient attention be paid to monthly reporting to the Agricultural Service in Brussels. He was clear that experts had to draw up the agricultural policy and not the Vice-Governor: We owe it to the Congo, as in Belgium, to have decisions made on judicial questions by magistrates, on military questions by officers, on questions of hygiene by doctors, and on agricultural questions by agronomists. This, however, did not end the friction between the local agricultural service and the general administration in Katanga. In 1915-1916, for example, the director of the Service foncier (the Land Agency) promoted the establishment of mainly Africans from Rhodesia and South Africa in the Elisabethville area, again with the primary motivation to produce more food for the mining population. But these African farmers would settle on land reserved for Belgian settlers. Of course, Leplae did not agree with this policy, and he ensured withdrawal of those measures. The absence of concrete results and a widespread displeasure about high costs also encouraged tension concerning agricultural colonisation between Brussels and Elisabethville ${ }^{44}$. The food prices in Katanga did not drop, because the Belgian settlers could not keep up with the rapidly increasing demand for food. The support measures and privileges enjoyed by the settlers came under increasing pressure. The local administration was gradually prioritizing the food security of the mining industry. Even if that had to be done through the stimulation of indigenous agriculture. Moreover, a similar adaptation of agricultural policy also occurred for instance in Nyasaland (Leplae, 1918; Palmer, 1985).

The negative comments of the local administration on the settlement scheme soon reached the metropole, where a liberal colonial study group connected to the Solvay In-

43. AA, AGRI 752, Correspondence Renkin with Vice-Governor Katanga, March 28, 1913; April 24, 1913 and June 13, 1913.

44. AA, AGRI 627, Correspondence between Leplae and Renkin, May 12, 1916. 
stitute wrote a very negative report on the colonization project in 1912. The low number of farmers and their lack of capital, the continuing high cost of living and the hasty implementation by the government were heavily criticized ${ }^{45}$. Although a previous study by this organization in 1910 had been positive about the European agricultural colonisation -also for indigenous agriculture-, the experts now stated that the colonisation project had been implemented too quickly and without sufficient thought (Hock, 1912) ${ }^{46}$. The Ligue Coloniale attached great importance to this report, especially when direct communication with the agricultural settlers showed that the situation in Katanga was not good at all. The Ligue therefore took on the critiques of the report and labelled the project as premature, while the colonial press took on this negative assessment.

When Britain finally acknowledged the borders of the Belgian Congo in 1913, the geopolitical argument for supporting agricultural colonisation disappeared. The presence of English settlers in Katanga no longer seemed threatening to the Belgian State. Therefore, it was no coincidence that an increasing number of politicians joined in the criticism of the Mission Agricole. During the discussion on the colonial budget in the Chamber of Representatives in March 1914, the argument really took off. The opposition, comprising of liberals and socialists, did not agree with the government policy. The Leplae report, which numbered 250 pages, though unfortunately has not been preserved, became the subject of intense discussions ${ }^{47}$. The high cost was the main point of contention. The opposition members estimated the expenditure at approximately between 7 and 13.2 million $\operatorname{BEF}(173,525$ and 327,219 Euro). In contrast, Minister Renkin kept his estimate to a conservative amount of 3 million BEF (or 74,338 Euro), of which less than half went to agricultural colonisation. However, the collapse of rubber prices in 1912-1913 forced the colonial authorities to curtail expenditure drastically, and the budget for supporting migrant farmers became one of the first victims. Several civil representatives called for an alternative way to invest the available resources. The liberals thought the mining sector was the best option, whilst the socialists preferred the indigenous farming population (Vandervelde, 1911 ${ }^{48}$. There was even criticism from the government's own ranks, and some recommended an alternative approach. For example, Catholic member of parlia-

45. AA, AEII 3610, Extrait de presse, Le Moniteur Industriel, 30/03/1912; AG, Ligue Coloniale Belge du Katanga, 6, Procès-Verbaux des Séances, February 2, 1912.

46. Le Katanga (1910: 30).

47. Leplae refers in his letter to Renkin of 12 May 1916 to the fameuse brochure bleu, which was presented to the Chamber on February 14, 1914. This report contained info about the costs of the agricultural policy in Katanga (circa 7 million BEF in 1911-1913). Leplae explains in his letter that he will not change a word in the report. Parlementaire handelingen, March 13, 1914, p. 1393.

48. Parlementaire handelingen, March 13, 1914, p. 1394; Parlementaire handelingen, March 12, 1914, pp. 1359-1361. 
ment Emile Tibbaut referred to it as a complete failure. Despite all the discussions, the parliament finally approved the budget, though the Agricultural Service's functionality did repeatedly come into question over the following years. Leplae's reaction demonstrated his irritation towards the criticism. He repeatedly stated that the agricultural colony in Katanga could only make a profit in the longer term, and that it required extensive financial efforts because of the numerous difficulties on the ground. He referred several times to the experiences in Southern Rhodesia, where the agricultural colonisation had also experienced a difficult period initially (Leplae, 1915a). Equally, it did not help that the temporary cessation of state-led migration did not end after the war. The guidance of the agricultural settlers was systematically transferred to the CSK, and gradually more attention focused on developing indigenous agriculture, which from 1917 was also subject to compulsory cultivation. Despite some revival attempts during the early 1930s, Leplae's plans for a large-scale agricultural migration to Katanga -and other regions in Belgian Congo- died a quiet death (Drachoussoff, Focan \& Hecq, 1991; Leplae, 1936) ${ }^{49}$.

\section{CONCLUSION}

In this article, we have analyzed the way in which various public and private actors set up the first agricultural colonization project in the Belgian Congo between 1908 and 1920, with a particular focus on the so-called Mission Leplae. Despite the short duration of this agricultural settler project and the limited number of farmers involved, this case offers important insights and conclusions regarding the political and economic history of Katanga and the Belgian Congo. Based on research of new and varied sources, as well as a thorough analysis of contemporary literature, this case study provides four main conclusions.

First, the Katangese case clearly shows that private initiative played an extremely important role in this first state-led migration. The burgeoning industry, co-represented at policy level by the CSK, responded to the geopolitical fears of the Belgian State to secure its food supply. The Pastorale, with a large number of Belgian industrialists on its board, also jumped onto the agricultural colonisation bandwagon and played a role as a pioneer. In Belgium, the strong influence of the Ligue Coloniale is also striking, as it represented the interests of both the homeland and the migrants themselves. Initially, the plan could only count on broad support in political and intellectual circles and the State could only expand the project in the form of the Agricultural Service by merging these different actors and their individual interests. However, when it became clear that settler farmers were

49. State Archives of Belgium (ARA), Fonds Hubert Droogmans, 185, Minute d'une mémoire "La colonisation et l'occupation des terres au Katanga", pp. 20-23. 
not meeting expectations to ensure the food supply for industrial workers, the alliance between public and private actors came to an end; between settler farmers and the Agricultural Service on the one hand, and industrial companies and local administration on the other hand. Moreover, that did not only happen in Katanga, but also in other African colonies, such as Nyasaland and Portuguese colonies in West and East Africa. The failure of the Pastorale clearly shows that the State was a vital trigger in this alliance. Without significant financial, material, and technical government assistance, the project never got off the ground, as shown by the limited increase in the number of Belgian farmers after the end of state support in 1913. However, it is also very clear that state aid alone is not a guarantee of success. This conclusion is consistent with other studies (Frankema, Green \& Hillbom, 2016).

Second, this case study clearly illustrates the extent to which the colonial State was fragmented during these first years of the Belgian Congo and fell prey to internal disagreements. The experiences of the Mission Leplae add nuance to the image of a homogeneous colonial State, and therefore the use of a single analytic frame is necessary. In addition, the division between colonial policy makers such as hommes politiques and technocratic experts clearly stands out. The Agricultural Service, both in Katanga and in Brussels (at the Ministry of Colonies), clashed several times with the local administrators, in which cases political strategies and modernization ideology had to cope with pragmatism, and with only varying degrees of success. The various attempts at agricultural colonisation show that colonial policy was in many cases a suboptimal compromise, obtained through a difficult balancing act between different actors and visions. The intended goals were usually only achieved partially and often resulted in undesirable effects, which the colonial government did not always have under control. It was chaotic and complex, with different actors playing different roles at different stages of the process. This is also why this article contributes to -and supports- the more recent analysis of European colonization as a far more heterogeneous process than previously thought.

Third, this case study illustrates how little familiarity the Belgian agronomists and scientists had with the agricultural conditions in Katanga and by extension in the colony itself. Initially they were very positive about the possibilities of developing a successful western agricultural economy, but the experts soon had to modify that view. The climatic conditions, the lack of livestock, numerous diseases, less fertile land and most importantly the labour scarcity, all this presented profound obstacles. Moreover, we should certainly not ignore the agricultural settlers themselves. The farmer migrants were not numerous, they were mainly small farmers with little financial strength and knowledge about tropical agriculture. And for that reason, the vast majority of farms did not have a long lifespan. On the other hand, some settlers managed to develop good relations with the staff 
of the Agricultural Service, which we can describe as a modest form of "settler empowerment". This gave them easier access to subsidies and practical support (for example, in the development of land and roads), which enabled them to further develop their farms or plantations.

Finally, it is clear that the know-how of Congolese farmers eventually proved to be too strong a competition for the Belgian newcomers in colonial agriculture, despite the difficulty of access to land for indigenous farmers and the numerous support measures for white settlers. The Agricultural Service attempted to cope with this adverse factor endowment and the lack of knowledge by investing in research, trial fields, and rolling out an early agricultural knowledge network, largely based on foreign examples and contacts. But the effect of those efforts would only be felt, at the earliest, from the 1920s onwards, although this also requires more historical research.

\section{ACKNOWLEDGEMENT}

The authors thank Leen Van Molle, Dries Claeys and Laura Eskens for their valuable comments on an earlier draft of this article. This research was funded by FWO-Flanders, research grant G.0B05.12N.

\section{REFERENCES}

AdAm, A., Bolle, A. \& Chaudoir, P. (1911). Le Katanga, province belge. Liège: Société belge d'études et d'expansion.

Beusekom, M.van (2002). Negotiating Development: African Farmers and Colonial Experts at the Office du Niger, 1920-1960. Portsmouth: Heinemann.

Bevel, M. L. (1935). Au Congo belge: Colonisation? Peuplement blanc? Brussels: Union office.

Bonello, J. (2010). The Development of Early Settler Identity in Southern Rhodesia: 1890-1914. The International Fournal of African Historical Studies, 43 (2), 341-367.

Booth, A. (2013).Varieties of Exploitation in Colonial Settings: Dutch and Belgian Policies in Indonesia and the Congo and their Legacies. In E. Frankema \& F. Buelens (Eds.), Colonial Exploitation and Economic Development:The Belgian Congo and the Netherlands Indies compared. London: Routledge.

BuELENs, F. (2007). Congo 1885-1960: Een financieel-economische geschiedenis. Berchem: EPO. 
Coghe, S. (2016). Reordering Colonial Society: Model Villages and Social Planning in Rural Angola, 1920-45. Fournal of Contemporary History, (52), 16-44.

Comité sPÉCIAL du KaTANGa (1950). Comité spécial du Katanga, 1900-1950. Bruxelles: Cuypers.

Drachoussoff, V., Focan, A. \& HecQ, J. (1991). Le développement rural en Afrique centrale 1908-1960/1962: Synthèse et réflexions. Bruxelles: Fondation Roi Baudouin.

FETTER, B. (1968). La création d'un colonat européen et la situation des africains au Katanga, 1916-1930. Etudes congolaises, 11 (4), 50-54.

FOUTRY,V. (1983). Belgisch-Kongo tijdens het interbellum: Een immigratiebeleid gericht op sociale controle. Belgisch Tijdschrift voor Nieuwste Geschiedenis, 14 (3-4), 461-488. Foutry, V. (1988). Les belges au Congo. In A. Morelli (Ed.), Les émigrants belges: Réfugiés de guerre, émigrés économiques, réfugiés religieux et émigrés politiques ayant quitté nos régions du XVième siècle à nos jours (pp. 169-184). Bruxelles: EVO.

Frankema, E., Green, E. \& Hillbom, E. (2016). Endogenous Processes of Colonial Settlement: The Success and Failure of European Settler Farming in Sub-Saharan Africa. Revista de Historia Económica-fournal of Iberian and Latin American Economic History, 34 (2), 237-265.

GofFART, F. (1912). Trois ans de colonisation belge au Katanga. Bruxelles: Goemaere.

GreEN, E. (2016). The Development of Settler Agriculture in British Africa Revisited: Estimating the Role of Tenant Labour in Southern Rhodesia, c. 1900-1960. Lund University African Economic History Working Paper Series, (29).

Hock, A. (1912). L'agriculture au Katanga: Possibilités et réalités. Bruxelles: Misch \& Thron.

Hillbom, E. \& Jenkin, S. (2018). Initial Conditions and Agricultural Development in Zambia, 1915-2015. In V. Pinilla \& H. Willebald (Eds.), Agricultural Development in the World Periphery: A Global Economic History Approach (pp. 153-178). Cham: Palgrave MacMillan.

Jewsiewicki, B. (1977). Unequal Development: Capitalism and the Katanga Economy, 1919-1940. In R. Palmer \& N. Parsons (Eds.), The Roots of Rural Poverty in Central and Southern Africa (pp. 317-342). London: Heinemann.

Jewsiewicki, B. (1979). Le Colonat Agricole Européen au Congo-Belge, 1910-1960: Questions politiques et économiques. The fournal of African History, 20 (4), 559-571. Jewsiewicki, B. (1980). African Peasants in the Totalitarian Colonial Society of the Belgian Congo. In M. A. KLEIN (Ed.), Peasants in Africa: Historical and Contemporary Perspectives (pp. 45-75). Beverly Hills: Sage.

KatZenellenbogen, S. E. (1973). Railways and the Copper Mines of Katanga. Oxford: Clarendon Press.

KeRCKHOfS, S. \& SEgers, Y. (2014). Crisis in de tropen: Landbouwpolitiek en agrarische wetenschap in Belgisch Congo (c. 1900-1940). In B. BLONDE et al. (Eds.), Overheid 
en economie: Geschiedenissen van een spanningsveld (pp. 133-152). Antwerp: University Press Antwerp.

L'agriculture au Katanga (Congo belge) (1918). Bulletin agricole du Congo belge, (9), 136-163.

Le KatANga (1910). Travaux du groupe d'études coloniales de l'Institut Solvay. Bruxelles: Misch \& Thron.

LEPLAE, E. (1909). Une exploitation agricole belge en Tunisie. Bruxelles: Expansion belge.

LEPLAE, E. (1911). Plans et photographies d'habitations pour plantations coloniales. Bruxelles: Imprimerie industrielle et financière.

LePlaE, E. (1913). L'agriculture du Congo belge: Rapport sur les années 1911 E 1912. Bruxelles: Imprimerie industrielle et financière.

LEPLAE, E. (1915a). Les débuts de la colonisation agricole en Rhodésie. Bulletin agricole du Congo belge, (6), 108-115.

LePLAE, E.(1915b). L'agriculture au Katanga, pendant le $2^{\mathrm{e}}$ semestre de l'année 1914. Bulletin agricole du Congo belge, (6), 72-91.

LEPLAE, E. (1918). La colonisation agricole belge au Congo. Bulletin agricole du Congo belge, (9), 3-28.

LEPLAE, E. (1921). Exploitation d'une ferme au Katanga et dans les régions élevées du Congo belge. Bulletin agricole du Congo belge, (12), 3-36, 134-148.

LePlaE, E.(1936). Une colonisation agricole belge au Congo? Leuven: Ceuterick.

Lutzelschwab, C. (2007). Populations et économies des colonies d'implantation européenne en Afrique. Annales de démographie historique, (113), 33-58.

MAZONDE, I. N. (1989). The Development of Ranching and Economic Enterprise in Eastern Botswana. Unpublished PhD. Manchester: Manchester University.

Molle, L.vaN (1989). Katholieken en landbouw: Landbouwpolitiek in België, 1880-1914. Leuven: Leuven University Press.

Morapedi, W. G. (2014). The Settler Enclaves of Southern Africa and the African Peripheral Areas (Reserves). South African Historical fournal, 66 (3), 546-571.

Mosley, P. (1982). Agricultural Development and Government Policy in Settler Economies: The Case of Kenya and Southern Rhodesia, 1900-1960. The Economic History Review, 35 (3), 390-408.

Musemwa, M. (2017). Narratives of Scarcity: Colonial State Responses to Water Scarcity in Southern Rhodesia, 1890-1965. In C. JoANaz DE Melo, E. VAZ \& L. M. Costa PINA (Eds.), Environmental History in the Making. II: Acting (pp. 263-290). Cham: Springer.

Mwatwara, W. \& Swart, S. (2016). 'Better Breeds?'The Colonial State, Africans and the Cattle Quality Clause in Southern Rhodesia c. 1912-1930. Fournal of Southern African Studies, 42 (2), 333-350. 
Mwitwa, K. (1988). Pouvoirs publics et petite colonisation agricole au Katanga 19101945. Unpublished PhD. Louvain: Université Catholique de Louvain.

NiNDI, B. C. (1987). Labour and Capital in Settler Economy in Colonial Tanganyika. fournal of Eastern African Research \& Development, (17), 90-96.

Palmer, R. (1977). Agricultural History of Rhodesia. In R. PAlmer \& N. PARsons (Eds.), The Roots of Rural Poverty in Central and Southern Africa (pp. 230-235). Berkeley: University of California Press.

Palmer, R. (1986). White Farmers in Malawi: Before and After the Depression. African Affairs, 84 (335), 211-245.

Robert, M. (1950). Le Katanga physique: Cinquantième anniversaire du Comité Spécial du Katanga. Bruxelles: Montana.

Segers, Y. (2003). Economische groei en levensstandaard: Particuliere consumptie en voedselverbruik in Belgie, 1800-1913. Leuven: Leuven University Press.

STANARD, M. G. (2014). Belgium, the Congo, and Imperial Immobility: A Singular Empire and the Historiography of the Single Analytic Field. French Colonial History, (15), 87-109.

STOLER, A. L. (1989). Rethinking Colonial Categories: European Communities and the Boundaries of Rule. Comparative Studies in Society and History, 31 (1), 134-161.

Stoler, A. L. (2010). Carnal Knowledge and Imperial Power: Race and the Intimate in Colonial Rule. Berkeley/Los Angeles: University of California Press.

UusihaKala, K. (2015). Rescuing Children, Reforming the Empire: British Child Migration to Colonial Southern Rhodesia. Identities, (22), 273-287.

VAndervelde, E. (1911). La Belgique et le Congo: Le passé, le présent, l'avenir. Paris: Alcan.

Vantemsche, G. (2007). Congo de impact van de kolonie op België. Tielt: Lannoo.

WilkIE, D. S. \& CuRRAN, B. (1993). Historical Trends in a Forager and Farmer Exchange in the Ituri Rain Forest of Northeastern Zaire. Human Ecology, (21), 389-417.

Woestenborghs, B., Hermans, R. \& Segers, Y. (2005). In het spoor van Demeter: Faculteit Bio-ingenieurswetenschappen K.U.Leuven, 1878-2003. Leuven: Leuven University Press.

Young, C. (1994). The African Colonial State in Comparative Perspective. New Haven: Yale University Press. 